\title{
THE PARADOXICAL PRESENCE OF EXODUS 34:6-7 IN THE BOOK OF THE TWELVE ${ }^{1}$
}

\author{
JP Bosman \\ Department of Old and New Testament \\ Stellenbosch University
}

\begin{abstract}
The theologically central "credo" of Exodus 34:6-7 is looked at in the context of the Old Testament in general, and in the Book of the Twelve in particular. The paradoxical nature of the way Exodus 34:6-7 is alluded to in 5 of the books of the Book of the Twelve (Hos 1:6, Joel 2:13, Jon 4:2, Mic 7:18-20 and Nah 1:3a) forms the basis of the argument. The theological issue at stake is the ambiguity and freedom of Yahweh's forgiveness and presence in the light of the crises of sin and exile. In the process the redactional (dis)unity of the Book of the Twelve is touched upon.
\end{abstract}

\section{Introduction}

After the Israelites broke the covenant with Yahweh through the Golden Calf incident (Ex 32), we find a series of dialogues between Yahweh and Moses as the representative of Israel (Ex 32:31-34; 33:1-5,12-23). The question if Yahweh will forgive and be with Israel after their sinful actions, remains unresolved (Ex 33:5). Moses pleads for Yahweh's forgiveness, and asks that Yahweh appear to him (Moses) in all his might as a sign of his presence with, and goodwill towards his people (Ex 33:16). Yahweh complies with Moses' request and orders him back to Sinai to receive the words of the law on two new flat stones (Ex 34:1-4). Yahweh appears to Moses in a cloud (Ex 34:5) and his decision on "what he is going to do with the people" (Ex 33:5), is revealed in a powerful self-declaration - Exodus 34:6-7:

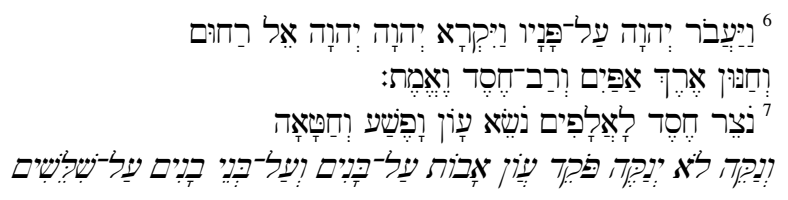

"And Yahweh passed in front of Moses, proclaiming: 'Yahweh, Yahweh, a God compassionate and gracious, slow to anger, and abounding in love and faithfulness. Maintaining love to thousands - forgiving guilt, rebellion and sin.

Yet definitively not leaving unpunished (the guilty). Calling to account the guilt of fathers on their sons and on the sons of their sons, to the third and fourth (generation)."

In this dramatic theophany, which is more an auditory than an optical revelation of God, we see the bipolar and ambiguous character of Yahweh is being revealed. This self-proclamation of God on his character and identity is one of the central confessions of Israel's faith. One could maybe even call it a credo. This statement which some call the "mercy formula" is prevalent

1. This article was fist presented as a paper at the 2003 OTSSA conference in Bloemfontein (2-4 September), which had as theme "Unity and diversity in the Book of the Twelve."

2. "Gnadenformel" (Spieckermann 1990:3). Cf. also Epiphanic formula (Weiser) and Prayer formula or Confession of faith (Scharbert and Dentan) (cited in Spieckermann 1990:3). 
throughout the whole Old Testament ${ }^{3}$. This bipolar contrast of God's mercy and justice has been formative in the Judeo-Christian religions and even in Islam. Every sûrah of the Qur'an starts with this confession of God's love: "In the name of Allah the Beneficent, the Merciful" and Sûrah 1 verse 2 and 3 of the "Seven oft-repeated" states: "The beneficent, the merciful. Owner of the day of judgment ${ }^{4}$." This ambiguous juxtaposition of Yaweh's characteristics is the focus of this article.

The paradoxical presence of Exodus 34:6-7 in the Book of the Twelve ${ }^{5}$ will be looked at. After making some methodological remarks, I will focus on the meaning of Exodus 34:6-7 in the context of the Book of Exodus. Then follows an overview of research on Exodus 34:6-7 in the Old Testament, after which the use of these verses in five of the books of the Book of the Twelve and its meaning for the Twelve as a whole will be put forward. The article ends with a short discussion of possible theological trajectories for our understanding of Exodus 34:6-7, as well as the message of the Book of the Twelve.

\section{Methodology: Alluding and quoting (Inter-textuality)}

Making a diachronic study of the presence of Exodus 34:6-7 is fraught with difficulty and has already been attempted by a scholar like Hermann Spieckermann, in his commendable 1990 ZAW article (Spieckerman 1990). Working with a so-called "synchronic" methodology is not any easier, although it would seem that the implicit uncertainty and speculation that goes with a diachronic study is somewhat lessened. A combined methodology that reads the texts as they come to us in their redacted final stages, but also tries to take into account the rhetoric as perceived in their differing historical originary contexts seems to be meaningful and also responsible.

My aim is to focus on the literary technique of quotation or allusion. In this regard I follow Eslinger (1992) who after giving a critique of Fishbane and Day's so-called inner biblical exegesis, opts for calling the study of inter-textual references or echoes in the Bible inner biblical allusion (Eslinger 1992:56). He shows how the historical-critical method and its aim of indicating which text "influenced" which other text, and in the process how the later text can be seen as an exegesis of the former, runs the danger of being circular reasoning (Eslinger 1992:52). He suggests that one self-consciously follow the lead of the Old Testament's own implied narrative and sequence of events and look for the "chain of reverse trajectory allusions through from creation to apocalypse" (Eslinger 1992:58). This boils down to reading the Bible from "start" to "finish." This, incidentally, is also what Book of the Twelve Scholars like Aaron Schart (1998:26) suggest for how we should read the 12 Minor Prophets. Start with Hosea.

A last methodological remark is about the way inter-textual echoes or quotations can be described. Vernon Robbins (1996) calls this ancient socio-rhetorical phenomenon the "Intertexture" of texts. According to him a major goal of intertextual analysis is:

"to ascertain the nature and result of processes of configuration and reconfiguration of phenomena in the world outside the text. Sometimes the text imitates another text but places different people in it. Sometimes it restructures a well-known tradition so that it ends differently or has very different implications for belief and action. Sometimes it inverts a tradition, turning the rhetoric of

3. Spieckermann (1990:1) sees the full formula used seven times (Ex 34:6, Joel 2:13, Jon 4:2, Pss 86:15, 103:8, 145:8, Neh 9:17) and partial allusions more than 20 times (e.g. Dtr 5:9-10, Num 14:18, Is 54:7-8, Dan 9:4, 2 Chr 30:9 etc.).

4. Cf. Pickthall, MM 1996. The meaning of the glorious Koran: An explanatory translation by Mohammed Marduke Pickthall. Delhi: Adam Publishers \& Distributors, p. 31.

5. This name for the Twelve Minor Prophets takes current research into the unity of these 12 "books" in one scroll, into consideration (cf. Redditt 2001). 
the previous situation on its head to create a new and distinct dramatic tradition" (Robbins 1996:40).

When language is used from other texts it can either be explicitly or without reference. We will look at the method of recitation, where the exact words of received speech is used (Robbins 1996:41-46), at recontextualization where it is not explicitly said that the words appear in another biblical text (Robbins 1996:48-50), and to the reality of cultural reference or allusion. A reference points to a known personage or tradition, whereas as an allusion presupposes a tradition that exists in textual form, but without attempting to "recite" the text (Robbins 1996:58). In the discussion of the texts below (Section 4), these categories will be used to describe the way Exodus 34:6-7 is re-used in the Book of the Twelve.

Using this way of looking at the intertexts of the Bible opens up interesting and usually paradoxical or ambiguous theological trajectories. This is no different with the Book of the Twelve, which in its final redactional forms I take to be an attempt at creating a unified Book of the Twelve. This links on to the current research into the Unity of the Book of the Twelve, a theoretical point of view which has even become a sub-category of research of the $S B L$. The theories of how this unity can be seen focus on many aspects of the text like superscriptions, catchwords or catchphrases at the beginnings and ends of books, allusions, shared themes, the overall plot as well as the different positions of the books in the Masoretic text, the Septuagint and Qumran (Redditt 2001:47).

One aim of this article is to explore how the paradoxical presence of Exodus 34:6-7 influences our views on the unity of the Twelve. Does the unity of the Twelve in fact rest on a theological unity?

\section{Exodus 34:6-7 in the Old Testament}

Exodus 34:6-7 has two big translation difficulties: Firstly, in verse 6 one is not certain who calls out (קרא) the confession about who God is. Is it Moses or Yahweh himself - the grammar makes both possible. With Houtman (2000:707) I see Yahweh as making a self-declaratory announcement, as a resuming of the theophany that started in Exodus 19. Secondly, the double repetition of $J H W H$ in verse 6 already troubled the Greek translators $\left(\mathrm{LXX}^{\mathrm{B}}\right)$ who left it out. It is to be kept as the first Yahweh can either be seen as the subject of exclamation, or as indicating the direct speech (Houtman 2000:708).

The important keywords in Exodus 34:6-7 that we will be searching for in the Book of the Twelve include:

:רחוּם Which means compassion and tenderness, almost like a mother towards her children.

חז: Indicating the Lord being merciful or gracious.

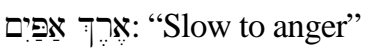

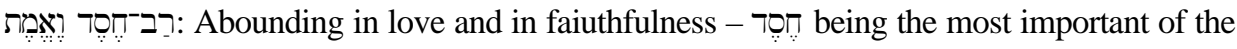

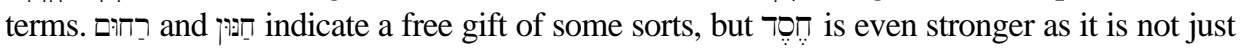
a gift but implies some kind of intimate relationship between the giver and receiver. indicates the Lord's steadfastness or being true to himself.

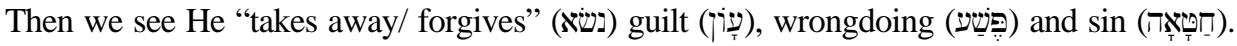
So far the one side of Yahweh's character - he is a loving God.

But Moses, the Israelites, and we also hear of Yahweh's other side. He is a God who: "Definitely will not leave unpunished" (infinitive absolute construction with the verb נקה) and "will call to account or avenge" (פקד) guilt/ wrongdoing. We see before us (as did 
Moses) a God who has a bipolar identity. It seems that there is a tension between his two sides - a fact that is not unknown in the world. In African religion in general God is experienced as merciful, but also one who is not without order, and therefore one who can punish $^{6}$. The meaning of Exodus 34:6-7 in the context of the Book of Exodus, and especially in the context of the Exodus narrative follows. The contribution of three scholars will be looked at.

\subsection{Exodus 34:6-7 in the context of the Book of Exodus}

Durham states that these verses were meant only for Israel's ears, and that the central question here is Yahweh's presence, which goes hand in hand with the threat of his absence (1987:451). Through theophany Yahweh's name is declared and his nature revealed in what Durham thinks is a very ancient Yahwistic confession of faith (1987:454). The confession fits the narrative perfectly with Yahweh's compassion and "slow anger" being demonstrated throughout the exodus and especially now after the golden calf incident (Durham 1987:454).

Brueggemann (1994) sees Exodus 34:6-7 as crisis evoked speech. Exodus 34:6-7 reacts to the crisis of the golden calf incident - the crisis of "covenant breaking" and the words רחוּים אמֶֶ provide the basis for life beyond the crisis (Brueggemann 1994:96). This leads to confident hope (Brueggemann 1994:104).

Houtman sees in Exodus 34:6-7 the "being with of Yahweh as an absolute requirement for life in the fullest sense of the term (2000:680). Like Durham he sees the theme as the presence or absence of Yahweh (Houtman 2000:682). The questions in the crisis are: Who is going to be Israel's guide in the Wilderness after the departure from Sinai? (Houtman 2000:683). In giving the answer the character of Yahweh is disclosed (Houtman 2000:708-709).

The idea of the presence of Yahweh could be further refined by indicating the ambiguous nature of the self-declaration.

First of all Exodus 32-34 seems to be quite an ambiguous section of Exodus. It is sandwiched between chapters 25-31 and 35-40 which all deal with the planning and the building of the Tabernacle. The tabernacle is the symbol of Yahweh's presence, his shekinah, his terrible glory. In between comes this strange story about covenant breaking with a golden calf, and the ensuing dialogue between Moses the mediator and Yahweh, the Liberator God who has become the Lawgiver. In the dialogue we see the precarious nature of the relationship between Yahweh and his people and it is only after many verses that Yahweh speaks the confession that He will forgive and we learn that he is indeed a stern Judge, but that his love is stronger. We learn that Yahweh is present, but that this presence is rather mysterious and ambiguous.

The same with Exodus 34:6-7 which contains an explicit ambiguity. We read that the Lord passed in front of Moses. Is this really possible? Did Yahweh really pass before Moses? Can one see Yahweh and live? The mysterious, ambiguous, paradoxical presence of Yahweh is showcased here in a very powerful way.

But let us turn to the way Exodus 34:6-7 was received and used in the rest of the Old Testament, and especially in the Book of the Twelve.

\subsection{Exodus 34:6-7 in the Context of the Old Testament}

The way Exodus 34:6-7 is alluded to in the OT is of course not a new question. There is a history of research on this very important question, Exodus 34:6-7 being one of the most

6. This I learned from a Zambian colleague in the Old Testament Post-Graduate seminar at Stellenbosch University, 2003. 
important credo's in the Old Testament as it forms the core of Israel's testimony of whom Yahweh is for them (or rather whom Yahweh declares himself to be).

Robert Dentan (1963) sees Exodus 34:6-7 as the original text and as part of the J-Document. He is certain that it is not part of the Deuteronomistic history, but that it is found in wisdom type texts, which can be attributed to the "wise men" who were the final redactors of the Old Testament. The text is alluded to or quoted in post-exilic times. It is liturgical in character and forms part of the universal message of the Bible.

Hermann Spieckerman (1990) makes a radical turn from this position by seeing Exodus 34:6-7 as late Deuteronomistic text that builds on Deuteronomy 7:9-10 as original text. The reception of Dtn 7:9-10 through Exodus 34, the psalms and importantly Jonah, Joel and Psalm 145 shows how this central tenet of Yahweh's character developed from a judging, punishing God, to one who shows mercy and is relenting, firstly to his own people, but in the end also universally to all the nations. This "mercy formula" is prayer literature and he thinks it forms part of the centre of the Old Testament's theology.

Thomas Raitt (1991:45) elaborates on the role Exodus 34:6-7 plays in being the "most important statement of forgiveness in the Old Testament." Like Spieckermann he sees a development of God's punishment being the focus to God's forgiveness being the central conviction - although the ensuing tension between the two must always be taken seriously (Raitt 1991:46). It was eventually used liturgically, because of "its careful structure and balanced structure, its wide influence, and its predominant reappearance in yet other liturgies" (Raitt 1991:48).

Raymond van Leeuwen (1993) brings us closer to our goal. He researched the way Exodus 34:67 was used in the Book of the Twelve to create a unity. Building on the work of Gerald Sheppard (1980), he argues that "the end-redaction of the Book of the Twelve is sapiential in character ... [employing] ... the bipolar attribute formula on YHWH's name from Exodus 34:67 as a base text in developing an overarching theodicy vis-à-vis the divine judgments of 722 and 587 BCE" (Van Leeuwen 1993:49). Exodus 34:6-7 therefore forms part of the final redaction of the Twelve by Wisdom traditions.

"By using the full bipolar contrast of mercy and justice from Exodus 34:6-7, the redactor affirms on the one hand, that Yahweh is free to exercise his forgiveness and mercy toward any who repent, and on the other, that he will not be held hostage to the evil of the wicked." ... [Van Leeuwen thinks it is] ... "this fearsome divine mystery, that governs the wisdom redaction of the Twelve as a whole, that creates its logic of theodicy" (Van Leeuwen 1993:49).

\section{Exodus 34:6-7 in the Book of the Twelve}

So far we have looked at the meaning of Exodus 34:6-7 in the context of Exodus, as well as theories about how the many allusions to Exodus 34:6-7 in the Old Testament can be understood. We have seen that Exodus 34:6-7 is probably original and sapiential (although Spieckermann disagrees). We have seen that there is probably a development from focusing solely on Yahweh's punishment to keeping his mysterious bipolar nature, which includes his love and mercy, in an ambiguous tension. Van Leeuwen goes so far as to see Exodus 34:6-7 as the wisdom "cement" which creates a unity in the Twelve. But what kind of unity is it really? 


\begin{tabular}{|c|c|c|c|c|c|c|}
\hline & $\begin{array}{l}\text { Name for } \\
\text { God }\end{array}$ & $\begin{array}{l}\text { Words for } \\
\text { mercy/ } \\
\text { forgiveness }\end{array}$ & $\begin{array}{l}\text { Words for } \\
\text { punishment }\end{array}$ & $\begin{array}{l}\text { Words for } \\
\text { sin }\end{array}$ & $\begin{array}{l}\text { Person } \\
\text { speaking }\end{array}$ & $\begin{array}{l}\text { Addressed } \\
\text { to Israel- } \\
\text { Judah or } \\
\text { Nations? }\end{array}$ \\
\hline $\begin{array}{l}\text { Exodus } \\
\text { 34:6-7 }\end{array}$ & $\begin{array}{l}\text { Yahweh + } \\
\text { El }\end{array}$ & 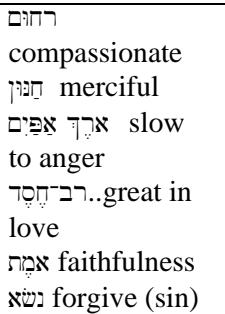 & 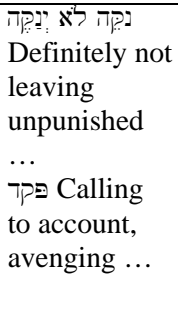 & 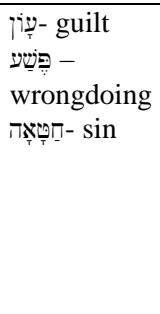 & $\begin{array}{l}1^{\text {st }} \text { person/ } \\
\text { (Yahweh } \\
\text { himself is } \\
\text { speaking in } \\
\text { a self- } \\
\text { declaration) }\end{array}$ & $\begin{array}{l}\text { "Israel" (at } \\
\text { Sinai) }\end{array}$ \\
\hline $\begin{array}{l}\text { Hosea } \\
1: 6\end{array}$ & (Yahweh) & $\begin{array}{l}\text { [Verb used in } \\
\text { a negative sense } \\
\text { (indicating } \\
\text { definite anti- } \\
\text { forgiveness)] } \\
\text { ם ["Take pity": } \\
\text { Again used in a } \\
\text { negative sense] }\end{array}$ & $\begin{array}{l}\text { לא רָחָָָה "Without } \\
\text { "With" } \\
\text { compassion" } \\
\text { (a negation of } \\
\text { the positive) } \\
\text { not show pity" } \\
\text { not sill }\end{array}$ & & $1^{\text {st }}$ person & Israel \\
\hline Joel 2:13 & $\begin{array}{l}\text { Yahweh } \\
\text { your God }\end{array}$ & 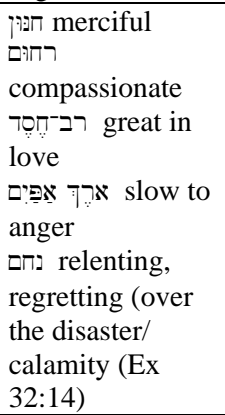 & & & $\begin{array}{l}3^{\text {rd }} \text { person } \\
\text { (Prophet to } \\
\text { people) }\end{array}$ & Judah \\
\hline $\begin{array}{l}\text { Jonah } \\
4: 2\end{array}$ & $\begin{array}{l}\text { Yahweh + } \\
\text { El }\end{array}$ & 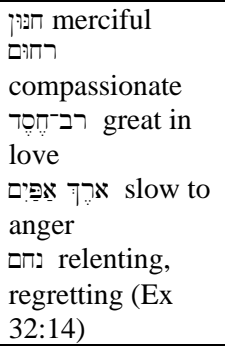 & & & $\begin{array}{l}2^{\text {nd }} \text { person } \\
\text { (Jonah to } \\
\text { God) }\end{array}$ & Assyrians \\
\hline $\begin{array}{l}\text { Micah } \\
\text { 7:18-20 }\end{array}$ & El & 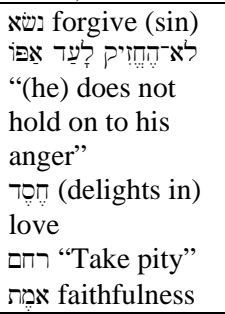 & & 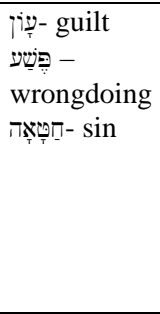 & $\begin{array}{l}2^{\text {nd }} \text { person } \\
\& \\
3^{\text {rd }} \text { person }\end{array}$ & Judah \\
\hline $\begin{array}{l}\text { Nahum } \\
\text { 1:3a }\end{array}$ & Yahweh & 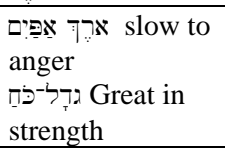 & 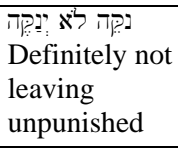 & & $3^{\text {rd }}$ person & $\begin{array}{l}\text { Assyria/ } \\
\text { Nineve }\end{array}$ \\
\hline
\end{tabular}

Figure 1: Comparison of 5 texts from the Book of the Twelve with Exodus 34:6-7. 
The table above (Figure 1) gives a quick graphic overview of the way Exodus 34:6-7 is alluded to in five texts in the Book of the Twelve. Note that all the texts allude to Exodus 34:6-7, but that Hosea 1:6 does so in the negative, Joel 2:13 and Jonah 4:2 add an allusion to Exodus 32:14, and Nahum 1:3a changes an important part of the "formula" (see the discussion of the texts below). A short exploration of these strongest allusions to Exodus 34:6-7 in the Twelve will help us to make some concluding remarks in the form of possible theological trajectories.

\subsection{Hosea 1:6}

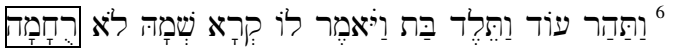

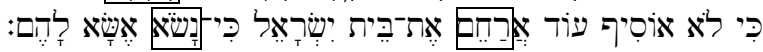

${ }^{6}$ (Gomer) conceived again and bore a daughter. Then the LORD said to him, "Name her

Lo-ruhamah, for I will no longer have pity on the house of Israel or forgive them.

As in Exodus 34:6-7 Yahweh himself speaks in the first person, and as in Exodus 34:6-7 he addresses Israel through the prophet. The name of the daughter plays on two of the central concepts of Exodus 34:6-7 namely Yahweh's compassion (רחם /רחּם ) and his forgiveness, (נשא). It is a cultural intertextual allusion in the sense that the precise text that lies behind this verse cannot be pinpointed. It is in fact an ironic recontextualisation of the positive statements in Exodus 34:6-7 and serves to highten the theological crisis which Israel is in. The names of Hosea's children function symbolically to indicate the end of Yahweh's friendly disposition, his protection and his providence (Jeremias 1983:32). The problem is the tension between Yahweh's love and his justice. In Hosea this tension is one of the central themes. Therefore we see in Hosea 5:8-6:6 how the Lord is a disease and a lion towards Israel, because they ran to foreign nations for help, but that at the end His love wins over and he becomes their healer again. The same is seen in the well-known Hosea 11 where God's love and his mercy goes against all human logic and wins over his plans for punishment (Jeremias 1983:140). The fact that the Book of the Twelve starts with this ironic negation of Yahweh's character points towards its centrality in understanding the rest of the Book.

\subsection{Joel 2:13}

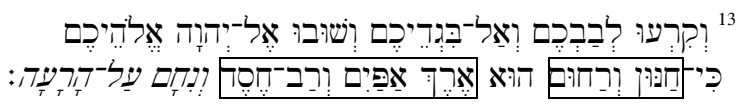

"rend your hearts and not your clothing. Return to the LORD, your God, for he is gracious and merciful, slow to anger, and abounding in steadfast love, and relents from punishing."

Here we have direct first person speech from Yahweh in verse 13a $\alpha$, but the prophet then takes up the speech in verse $13 \mathrm{a} \beta$ speaking to Judah about Yahweh in the third person. This move away from the fiery self-declaration in Exodus 34:6-7 creates more distance, and holds more threat. We have recitation of Exodus 34:6-7, with the replication of the exact

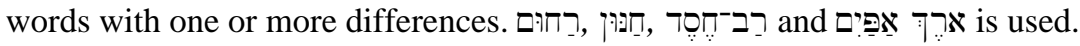

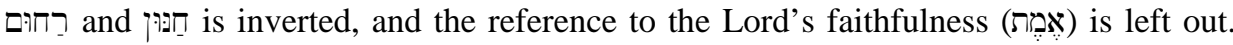
We actually have a combined recitation as the last part of the verse alludes to Exodus 32:14 where Yahweh relents about bringing disaster on Israel after the golden calf incident. The question of Yahweh's mercy and his forgiveness for his own people is stated in the context 
of the looming and terrible day of the Lord (Zenger et al 1998:483), while "at the same time stress[ing] that there is still hope that the people will repent"(Prinsloo 1985:51). Verse 14 points to the uncertainty and ambiguity of Yahweh's presence: "Who knows (מִי יוֹטעי) if he will not turn and relent." Zenger et al (1998:483) calls this a dialectical image of God, which in the context of the eschatological dialectic of disaster and salvation, points to God's goodness and love, which is worked out in divine freedom. Prinsloo (1985:58) points to the freedom of God as this expression ("Who knows") "indicates that there is no direct, causal connection between the people's penitence and Yahweh's response ... [h] retains his sovereignty."

This seems to be pointing in the same direction of Exodus 34:6-7 with the uncertainty of the crisis of covenant-breaking calling forth ambiguous speech about Yahweh's mysterious and free presence and forgiveness.

\subsection{Jonah 4:2}

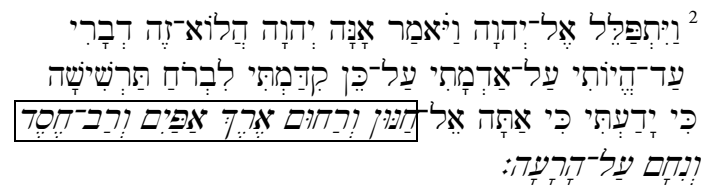

${ }^{2}$ He prayed to the LORD and said, "O LORD! Is not this what I said while I was still in my own country? That is why I fled to Tarshish at the beginning; for I knew that you are a gracious God and merciful, slow to anger, and abounding in steadfast love, and ready to relent from punishing.

This verse forms the central theological tenet of Jonah and the recitation is used exactly like in Joel 2:13, except that the prophet is not speaking to Israel or Judah (or is he?) but addresses Yahweh in the second person. The whole allusion becomes a radical recontextualization as the issue is not about the ambiguous presence of Yahweh with his own people, but the fact that this central confession about what or who Yahweh is for his own people seems to be true for other nations as well. The ambiguity about Yahweh's mercy or his relenting is also echoed ironically in Jonah when the king of Nineveh states: "Who knows?" (מִי יוֹדֵט) - God may relent and change his mind." Whereas Joel took Exodus 34:67 to be an ambiguous, but powerful confession about Yahweh's particular and exclusive forgiving presence for his own people, the book of Jonah uses Exodus 34:6-7 as an ironic universalising extension of Yahweh's bipolar character not just to Israel but to all nations who repent (Zenger et al 1997:502) ${ }^{7}$.

\subsection{Micah 7:18-20}

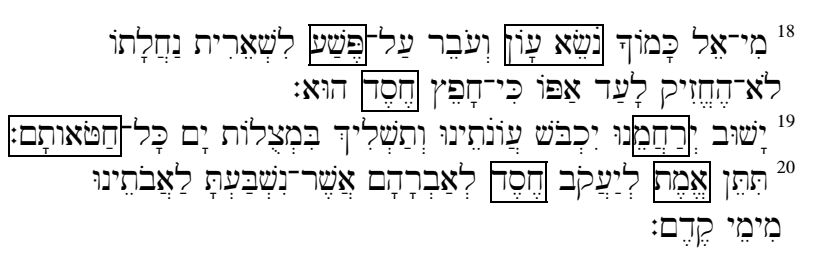

7. Van der Woude (1985:53-54) questions this nationalistic-particularistic versus universalistic interpretation of the text, and explains Jonah's anger as directed against God himself for being inconsequent and therefore placing his own (and his messenger's!) honour on the line. 
${ }^{18}$ Who is a God like you, pardoning iniquity and passing over the transgression of the remnant of your possession? He does not retain his anger forever, because he delights in showing clemency.

${ }^{19}$ He will again have compassion upon us; he will tread our iniquities under foot. You will cast all our sins into the depths of the sea.

${ }^{20}$ You will show faithfulness to Jacob and unswerving loyalty to Abraham, as you have sworn to our ancestors from the days of old.

These last verses of Micah form, not only the end of this prophetic book, but also the end of the first half of the Book of the Twelve. Micah 7:18-20 contains most of the keywords of Exodus 34:6-7 dispersing them across 3 verses and changing their original order. One could in fact ask if we have any reference, or allusion here at all. The fact is that forgiving (נשא), compassion or

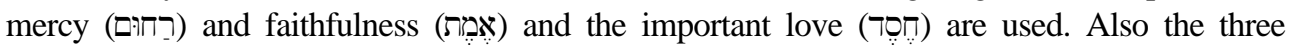

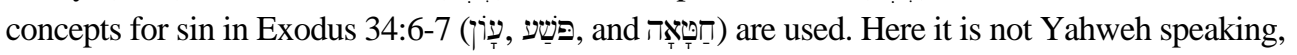
but the prophet speaking in a peculiar mixture of second and third person to, or about Yahweh. These verses form the ending of the book, which, after explaining Yahweh's punishment of Israel in the past, now has to point towards an idealized future (Ben Zvi 2000:11 ${ }^{8}$ ). They want to give hope for the future and point towards the forgiveness of all sin after all the preceding "hard words" in Micah 1:2-7:6 (Wolff 1982:210). In this sense it picks up the central theme of Exodus: Will Yahweh be present and guide Israel into their uncertain future in the wilderness. The difficult theological statement with which the Book of the Twelve opened - Yahweh will not have compassion (Hos 1:6 רבחוּם) - is now returned to at the end of the first half. Yahweh indeed will show compassion again and it seems that his love and forgiveness still wins over his punishment.

So far all the allusions in the Book of the Twelve referred only to Yahweh's positive side, as this created hope for Israel's future, or created a theological crisis with his merciful side also being available to repenting foreign nations. In Nahum this changes.

\subsection{Nahum 1:3a}

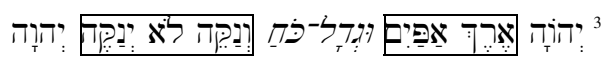

${ }^{3}$ The LORD is slow to anger but great in power, and the LORD will by no means clear the guilty.

Here we have a recitation, which contains replication and omission of words so that the verse has the force of an authoritative judgment. Like in Exodus 34:6-7 the context is a theophany, but unlike Exodus, it is not Yahweh making a self-declaration, but a $3^{\text {rd }}$ person prophetic hymn about Yahweh. This again creates more distance, but in this case it is a powerful and judging distance, as the topic is the punishment of a foreign enemy of Israel. The credo starts off like in Exodus 34 "slow to anger," but where we would expect "great in love (חסרד) it is changed to

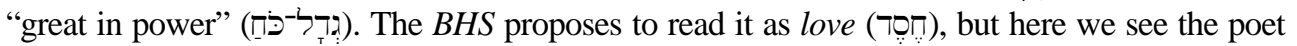
putting "his own stamp on the traditional formulae" and that the "original positive message was 'vengefully reapplied' ... to underline the announcement of YHWH's anger coming upon his enemies" (Spronk 1997:36-37). Then the punishment side of Yahweh's character follows by exact replication of Exodus 34:7b "he will definitely not leave the guilty unpunished." Here the focus is not Israel but a foreign nation, and the message is clear. Jonah's experience of God as

8. Zenger et al (1998:504-506) sees Micah 7:18-20 (salvation for Israel) as forming a theocentric frame with Micah 1:3-7 (judgment on Israel). 
also being ambiguously present in mercy to repenting nations is not applicable. His slowness to anger serves as an explanation why his punishment and judging is put off, but in the end punishment and disaster will strike Assyria. In this sense, the use of the formula does indirectly link towards Yahweh's continuing presence with Israel, and gives an explanation for the theodicy of exile and oppression. The answer is indeed a bit ambiguous, as the use of the confession as a weapon or maxim of judgment occurs in a possible partial, broken acrostic. Even such a statement of judgment is imbedded into the paradoxical experience of reality, which is more often than not chaotic, broken and uncertain.

To summarize we could say that in the Book of the Twelve the echoes of Exodus 34:6-7 indeed play an important role. It is also clear that the formula is not used in the same way. The original text is changed and recontextualized. Its theological consequences are used in different ways to answer different questions in different contexts. It seems that all the uses of Exodus 34:6-7 do somehow point towards Yahweh's mercy towards Israel - but that the ambiguity and paradox of that mercy is also very clear. What was meant for Israel's ears as a self-declaration from Yahweh, has become echoes about or to Yahweh, about Israel or about foreign nations. The complex and ambiguous question of Yahweh's presence is worked out in different strings and degrees to fit different crises.

\section{Theological Trajectories}

The question about Yahweh's forgiveness and his continuing presence in post-exilic Judah after the destruction of the temple is central. The use of Exodus 34:6-7 is a way of dealing with the crisis of the exile and the question of theodicy. Will Yahweh still be present, although his temple, the symbol of his tabernacling presence has been destroyed? The answer is a hopeful yes, although the realisation of Yahweh's total freedom is held in tension. Who knows if God will relent? In that way Exodus 34:6-7 can indeed be seen as a "cement" used to bring about some kind of unity in the Book of the Twelve. On the other hand the "formula" is echoed only in five of the twelve books and when it is used it seems to be in a theologically paradoxical manner. It is used in the most contrasting books of the Twelve, Joel, Jonah and Nahum, its use implying contrasting theological affinities.

What does seem to be central to all the texts in question is the ambiguity of Yahweh's presence. Maybe Exodus 34:6-7 was used by redactors to bring a unity to the Book of the Twelve, but this unity is then also paradoxical and ambiguous. We should maybe rather say that it points not to the redactors' creation of unity, but that it points towards their respect for the Book's disunity. Does the paradoxical presence of Exodus 34:6-7 not point towards the paradoxical and mysterious presence of the Presence itself?

The idea of the sages, or wisdom, having the last word in the Twelve (or maybe even in the Old Testament ${ }^{9}$ ) is maybe not such a far fetched one. After all the sages (or the teachers) are the ones who deal with life in all its beautiful and terrible incomprehensibility. Their final words point to Yahweh and his presence, but it ends not with a full stop, but with a mysterious (wise) comma. Let those who have ears listen, for:

"Those who are wise understand these things;

those who are discerning know them" (Hosea 14:9a)

9. Cf. Sheppard who looked at Wisdom as hermeneutical construct: A study in the sapientializing of the Old Testament (1980). He comes to the conclusion that “... the OT redactions which were studied suggest that wisdom was assumed to have a hermeneutical function in the context of the canon and that it offered a model for the interpretation of other biblical narrative, prophetic, and hymnic texts as a guide to the obedient life" (Sheppard 1980:159). 


\section{BIBLIOGRAPHY}

Ben Zvi, E 2000. Micah (FOTL Volume XXIB). Grand Rapids: William B Eerdmans.

Brueggemann, W 1994. Crisis-evoked, crisis-resolving speech. Biblical Theology Bulletin 24/3:95-105.

Dentan, RC 1963. The literary affinities of Exodus XXXIV 6f. VT 13:34-51.

Durham, JI 1987. Exodus (WBC). Waco: Wordbooks.

Eslinger, L 1992. Inner-biblical exegesis and inner-biblical allusion: The question of category. VT XLII/1:47-58.

Houtman, C 2000. Exodus Volume 3, Chapters 20-40 (HCOT). Leuven: Peeters.

Jeremias, J 1983. Der Prophet Hosea (ATD 24/1). Göttingen: Vandenhoeck \& Ruprecht.

Pickthall, MM 1996. The meaning of the glorious Koran: An explanatory translation by Mohammed Marduke Pickthall. Delhi: Adam Publishers \& Distributors.

Prinsloo, WS 1985. The theology of the Book of Joel (BZAW 163). Berlin: Walter de Gruyter.

Raitt, TM 1991. Why does god forgive? Horizons in Biblical Theology 13/1:38-58.

Redditt, PL 2001. Recent research on the Book of the Twelve as one book. CR:BS 9:47-80.

Robbins, VK 1996. Exploring the texture of texts: A guide to socio-rhetorical interpretation. Valley Forge: Trinity Press International.

Schart, A 1998. Die Entstehung des Zwölfprophetenbuchs: Neubearbeitungen von Amos im Ramen schriftenübergreifender Redaktionsprozesse (BZAW 260). Berlin: Walter de Gruyter.

Sheppard, GT 1980. Wisdom as hermeneutical construct: A study in the sapientializing of the Old Testament (BZAW 151). Berlin: Walter de Gruyter.

Spieckermann, H 1990. "Barmherzig und gnädig ist der Herr ..." ZAW 102:1-18.

Spronk, K 1997. Nahum (HCOT). Kampen: Kok Pharos Publishing House.

Van Der Woude, AS 1985. Jona - Nahum (De Prediking van het Oude Testament). Nijkerk: GF Callenbach.

Van Leeuwen, RC 1993. Scribal wisdom and theodicy in the Book of the Twelve, in: Perdue, LG, Scott, BB \& Wiseman, WJ (eds.) 1993. In search of wisdom: Essays in memory of John G. Gammie, 31-49. Louisville: Westminster Press.

Wolff, HW 1982. Micha -Dodekapropheton 4 (BK XIV/4). Neukirchen-Vluyn: Neukirchener Verlag.

Zenger, E et. al. 1998. Einleitung in das Alte Testament, 3. Auflage. Stuttgart: W Kohlhammer. 